\title{
Investigation of Sintered Cobalt-zinc Ferrite Synthesized by Coprecipitation at Different Temperatures: A Relation between Microstructure and Hysteresis Curves
}

\author{
Ana Maria Rangel de Figueiredo Teixeira*, Tsuneharu Ogasawarab, Maria Cecília de Souza Nóbrega ${ }^{\mathrm{b}}$ \\ a Department of the Analytical Chemistry, Fluminense Federal University, Niteroi, RJ, Brazil \\ ${ }^{\mathrm{b}}$ Department of Metallurgical and Materials Engineering of COPPE, \\ Federal University of Rio de Janeiro, RJ, Brazil
}

Received: August 1, 2005; Revised: August 16, 2006

\begin{abstract}
The magnetic properties of sintered samples of cobalt-zinc ferrites produced from the corresponding coprecipitate were calculated based on hysteresis curves (Hc). The Hc values confirmed that soft ferrites were obtained by the procedure. A possible relation between the magnetic hysteresis curves and the microstructure of the sintered samples was investigated. $\mathrm{X}$ ray diffraction, thermal analysis and scanning electron microscopy were used to characterize the microstructure and the phases present in the sintered ceramic pieces, as well as those of their coprecipitated tri-metallic hydroxide precursor powders. It was found that sintering of $\mathrm{Co}_{0.5} \mathrm{Zn}_{0.5} \mathrm{Fe}_{2} \mathrm{O}_{4}$ at $1400{ }^{\circ} \mathrm{C}$ led to "honeycombing" of the ferrite grains and that there was no single phase in the microstructure of a sample sintered at $1400{ }^{\circ} \mathrm{C}$. Thus, a more complete study was made of the behavior of the microstructure at lower sintering temperatures, i.e., in the $1100-1350{ }^{\circ} \mathrm{C}$ range.
\end{abstract}

Keywords: cobalt-zinc ferrite, hysteresis curve, coprecipitation

\section{Introduction}

Studies of spinel ferrites are highly relevant to modern technologies, so the synthesis and sintering of ferrites have become an important part of modern ceramic research ${ }^{1-3}$. Cobalt-zinc ferrite is one of the soft ferrites used in electronic devices such as transformer cores, electric motors and generators. In its applications, it is subjected to alternating magnetic fields, and should therefore present low energy losses. $\mathrm{Co}_{(1-\mathrm{x})} \mathrm{Zn}_{\mathrm{x}} \mathrm{Fe}_{2} \mathrm{O}_{4}$ ferrites with $x$ ranging from 0.1 to 0.5 prepared by the coprecipitation method have not yet been as extensively studied as $\mathrm{Mn}-\mathrm{Zn}$ and $\mathrm{Ni}-\mathrm{Zn}$ substituted ferrites $\mathrm{s}^{2,4,5}$ have.

The distribution of the cations in cobalt-zinc ferrite can be represented by $\mathrm{Zn}^{2+}{ }_{\mathrm{x}} \mathrm{Fe}^{3+}{ }_{1-x}\left[\mathrm{Co}^{2+}{ }_{1-x} \mathrm{Fe}^{3+}{ }_{1+x}\right] \mathrm{O}_{4}^{6-8}$. The substitution of $\mathrm{Zn}^{2+}$ for $\mathrm{Fe}^{3+}$ reduces the Curie temperature of the ferrite ${ }^{6,7,9}$. On the other hand, increasing the zinc content of cobalt-zinc ferrites increases their lattice parameter ${ }^{10-12}$ while decreasing the saturation magnetization due to augmented B-B interaction followed by reduced A-B interaction. Also, the presence of $\mathrm{Co}^{2+}$ ion in the cobalt-zinc ferrite hastens the $\mathrm{Co}^{2+}+\mathrm{Fe}^{3+} \Leftrightarrow \mathrm{Co}^{3+}+\mathrm{Fe}^{2+}$ exchange reaction in octahedral sites, while tetrahedral sites are preferentially occupied by zinc cations. This exchange reaction supports the electronic conduction mechanism in cobalt-zinc ferrites ${ }^{12,13}$; the octahedral sites become enlarged when they are occupied by $\mathrm{Fe}^{2+}$ ions instead of $\mathrm{Co}^{2+}$ ions ${ }^{6,8,14}$.

In this study, the cobalt-zinc ferrite precursor was prepared by coprecipitation from an aqueous solution of the pure salts of the cations, a method that offers the advantage of easy and homogeneous mixing of the main components. The purpose of this study was to investigate the possible relation between the magnetic hysteresis curves and the microstructure of sintered $\mathrm{Co}_{0.5} \mathrm{Zn}_{0.5} \mathrm{Fe}_{2} \mathrm{O}_{4}$.

\section{Experimental Procedure}

The starting material was an aqueous solution of pure cobalt, zinc and ferric nitrates in a molar ratio of 1: 1: 4. Titration by $\mathrm{NH}_{4} \mathrm{OH}$ or $\mathrm{NaOH}$ yielded a triple hydroxide precipitate at $\mathrm{pH} 10$. Filtration, care- ful drying in a furnace and calcination at $400{ }^{\circ} \mathrm{C}$ for 5 hours resulted in anhydrous triple-oxide with minimum particle aggregation.

The heat-treated samples were characterized by $\mathrm{X}$ ray diffraction to ascertain the effective formation of the desired cobalt-zinc ferrite. All the samples were analyzed with a Phillips $X$ ray diffractometer using $\operatorname{CoK} \alpha\left(\lambda=1.79 \mathrm{~A}^{\circ}\right)$ radiation.

The thermal behavior of the ferrite powder was monitored by TG and DTA, with the sample heated to a maximum of $1400{ }^{\circ} \mathrm{C}$ under synthetic air (Neztsch, Luxx $409 \mathrm{STA}$ ). The $\mathrm{Co}_{0.5} \mathrm{Zn}_{0.5} \mathrm{Fe}_{2} \mathrm{O}_{4}$ powder containing $2 \mathrm{wt}$. (\%) of polyvynil alcohol (PVA) was pressed into ringshaped compacts (rectangular cross section, $1.7 \mathrm{~cm}$ outer diameter and $0.6 \mathrm{~cm}$ inner diameter) under $1.5 \mathrm{ton} / \mathrm{cm}^{2}$ for 1 minute in a steel die. The compacts weighed about $2.50 \mathrm{~g}$ before sintering and were sintered at preset temperatures $\left(950,1100,1200,1300,1350\right.$ and $\left.1400^{\circ} \mathrm{C}\right)$ for 5 hours. The heating rate applied was $4{ }^{\circ} \mathrm{C} / \min$ up to $600^{\circ} \mathrm{C}$, where the compacts were held for 1 hour to eliminate PVA, after which this rate was increased to $8{ }^{\circ} \mathrm{C} / \mathrm{min}$ up to the sintering temperature. The sintered compacts were analyzed by atomic absorption spectrometry, $\mathrm{X}$ ray diffraction (XRD), and scanning electron microscopy (SEM). One sintered compact from each sintering temperature was equipped with varnished copper wire winding for use as a solenoid, which was then subjected to magnetic hysteresisgraphy using a Walker Scientific model AMH-20 hysteresisgraph at a frequency of $60 \mathrm{~Hz}$.

\section{Results and Discussion}

\subsection{Characterization of the powder}

Figure 1 presents a TGA-DTA graph in the range of 25 to $1000{ }^{\circ} \mathrm{C}$ for a $\mathrm{Co}_{0.5} \mathrm{Zn}_{0.5} \mathrm{Fe}_{2} \mathrm{O}_{4}$ powder coprecipitate. The DTA graph shows an endothermic reaction at about $260^{\circ} \mathrm{C}$, which corresponds, on the TGA graph, to a $35.85 \%$ weight loss (elimination of ammonium hydroxide used as precipitant; dehydration of hydroxides). 
An exothermic reaction between 575 and $925^{\circ} \mathrm{C}$, corresponding on the TGA graph to a $16.75 \%$ weight loss, suggests that the ferrite still contains hydroxyl groups, which is congruent with the exothermic band depicted in the DTA graph. According to the literature ${ }^{5}$, hydroxyl groups are retained in $\mathrm{Co}_{0.5} \mathrm{Zn}_{0.5} \mathrm{Fe}_{2} \mathrm{O}_{4}$ even after sintering at $700{ }^{\circ} \mathrm{C}$ and are completely removed after sintering at $925{ }^{\circ} \mathrm{C}$. A similar behavior was observed ${ }^{5}$ for $\mathrm{Co}_{0.2} \mathrm{Zn}_{0.8} \mathrm{Fe}_{2} \mathrm{O}_{4}$ prepared by coprecipitation, but the exothermic band ended at $550{ }^{\circ} \mathrm{C}$. The presence of hydroxyl groups has also been reported ${ }^{3}$ in nanocrystalline ferrite powders prepared by hydrothermal synthesis. The weight loss occurring between 300 and $600{ }^{\circ} \mathrm{C}$ is not significant but, in this range, the DTA graph shows an exothermic band, which may be due to the formation of spinel ferrite.

Figure 2 shows the $\mathrm{X}$ ray diffraction patterns of the powder samples precipitated by $\mathrm{NaOH}$ and $\mathrm{NH}_{4} \mathrm{OH}$ in the same time period but at different temperatures. The peaks observed here were found to correspond to those of standard diffraction patterns of a spinel ferrite ${ }^{15}$ with no extra peaks, confirming that the cubic ferrite phase was formed in all the samples.

An $X$ ray diffraction pattern similar to that shown in Figures 2a and $2 \mathrm{~b}$ indicated that both precipitants can be used. However, when ammonium hydroxide is used as the precipitating agent, the $\mathrm{pH}$ must be strictly controlled because complexes with zinc ${ }^{17}$ can be formed and zinc ions may remain in the solution, influencing the ferrite's molar ratio. Therefore, sodium hydroxide was chosen as the precipitant in this study. The XRD pattern also showed that the ferrite phase was dependent on the reaction temperature. The sample heated to $200{ }^{\circ} \mathrm{C}$ presented mostly an amorphous phase (Figure 2c), but peaks (311) and (440) attributed to the spinel phase began to appear. The powders treated at $400{ }^{\circ} \mathrm{C}$ presented a high level of crystallization. The literature ${ }^{1,5,17}$ cites similar results for several spinel ferrites with high levels of crystallization.

The lattice parameter for the ferrite powder prepared at $400{ }^{\circ} \mathrm{C}$ was calculated as $8.38 \AA$ based on the XRD pattern. This result was confirmed by the literature ${ }^{1,6}$ (which cites values of 8.37 and $8.36 \AA$ ).

\subsection{Characterization of the sintered material}

The sintered compacts were characterized by XRD to confirm the phase purity and crystallinity. The diffraction angles $(2 \theta)$ of the cobalt-zinc ferrite were calculated at different sintering temperatures (Table 1), based on the $\mathrm{X}$ ray diffraction pattern. The values remained essentially constant in the range of $950-1350{ }^{\circ} \mathrm{C}$, but clearly differed at $1400{ }^{\circ} \mathrm{C}$, indicating the onset of a phase transformation just above $1350{ }^{\circ} \mathrm{C}$, which means that $\mathrm{Co}_{0.5} \mathrm{Zn}_{0.5} \mathrm{Fe}_{2} \mathrm{O}_{4}$ cannot be produced above that temperature. The strongest reflection came from the $(3,1,1)$ plane for all ferrites sintered from 950 to $1350^{\circ} \mathrm{C}$, while the strongest reflection for the ferrite sintered at $1400{ }^{\circ} \mathrm{C}$ came from the $(4,4,4)$ plane.

Table 2 presents the true density (Dx) of sintered $\mathrm{Co}_{0.5} \mathrm{Zn}_{0.5} \mathrm{Fe}_{2} \mathrm{O}_{4}$ obtained in this work, which was calculated based on the XRD as a function of the sintering temperature. These values range from 5.29 to $5.35 \mathrm{~g} / \mathrm{cm}^{3}$ and are congruent with the reported ${ }^{9}$ value of $5.30 \mathrm{~g} / \mathrm{cm}^{3}$ for $\mathrm{Co}-\mathrm{Zn}$ ferrite also prepared by coprecipitation. The true density of the material sintered at $1400{ }^{\circ} \mathrm{C}$ was not calculated because the diffraction peaks could not be assigned to the $\mathrm{Co}_{0.5} \mathrm{Zn}_{0.5} \mathrm{Fe}_{2} \mathrm{O}_{4}$. This is evidence of the presence of extra phases.

The morphologies of the coprecipitated $\mathrm{Co}_{0.5} \mathrm{Zn}_{0.5} \mathrm{Fe}_{2} \mathrm{O}_{4}$ compacts sintered at different temperatures $\left(950^{\circ} \mathrm{C}\right.$ to $\left.1400^{\circ} \mathrm{C}\right)$ were examined. The compact sintered at $950{ }^{\circ} \mathrm{C}$ was characterized by the presence of different grain sizes (ranging from $1 \mu \mathrm{m}$ to $10 \mu \mathrm{m}$ ), as depicted in Figure 3a. Sintering at 1100 and $1200{ }^{\circ} \mathrm{C}$ (Figures 3b, 3c) produced the familiar spinel crystals $(15 \mu \mathrm{m}$ and $20 \mu \mathrm{m}$, respectively). The cobalt-zinc ferrite compact sintered at $1300{ }^{\circ} \mathrm{C}$ (Figure $3 \mathrm{~d}$ ) showed rounder grains larger than $30 \mu \mathrm{m}$, indicating signs of the onset of intragranular "honeycombing". This honeycombing phenomenon intensified in the ferrite compact sintered at $1350^{\circ} \mathrm{C}$ (Figure $3 \mathrm{e}$ ), whose

Table 1. Data from X ray diffraction patterns of Co-Zn ferrites sintered at different temperatures.

\begin{tabular}{crccc}
\hline & $950-1350{ }^{\circ} \mathrm{C}$ & \multicolumn{2}{c}{$1400{ }^{\circ} \mathrm{C}$} \\
$2 \theta$ & $\mathrm{I}(\%)$ & $(\mathrm{h}, \mathrm{k}, \mathrm{l})$ & $2 \theta$ & $\mathrm{I}(\%)$ \\
\hline 35.3 & 10 & $2,2,0$ & 28.9 & 11 \\
41.3 & 100 & $3,3,1$ & 30.5 & 25 \\
50.4 & 20 & $4,0,0$ & 48.9 & 23 \\
65.7 & 18 & $4,2,2$ & 68.8 & 55 \\
69.1 & 40 & $5,1,1$ & 71.8 & 100 \\
73.2 & 50 & $4,4,0$ & 84.4 & 10 \\
\hline
\end{tabular}

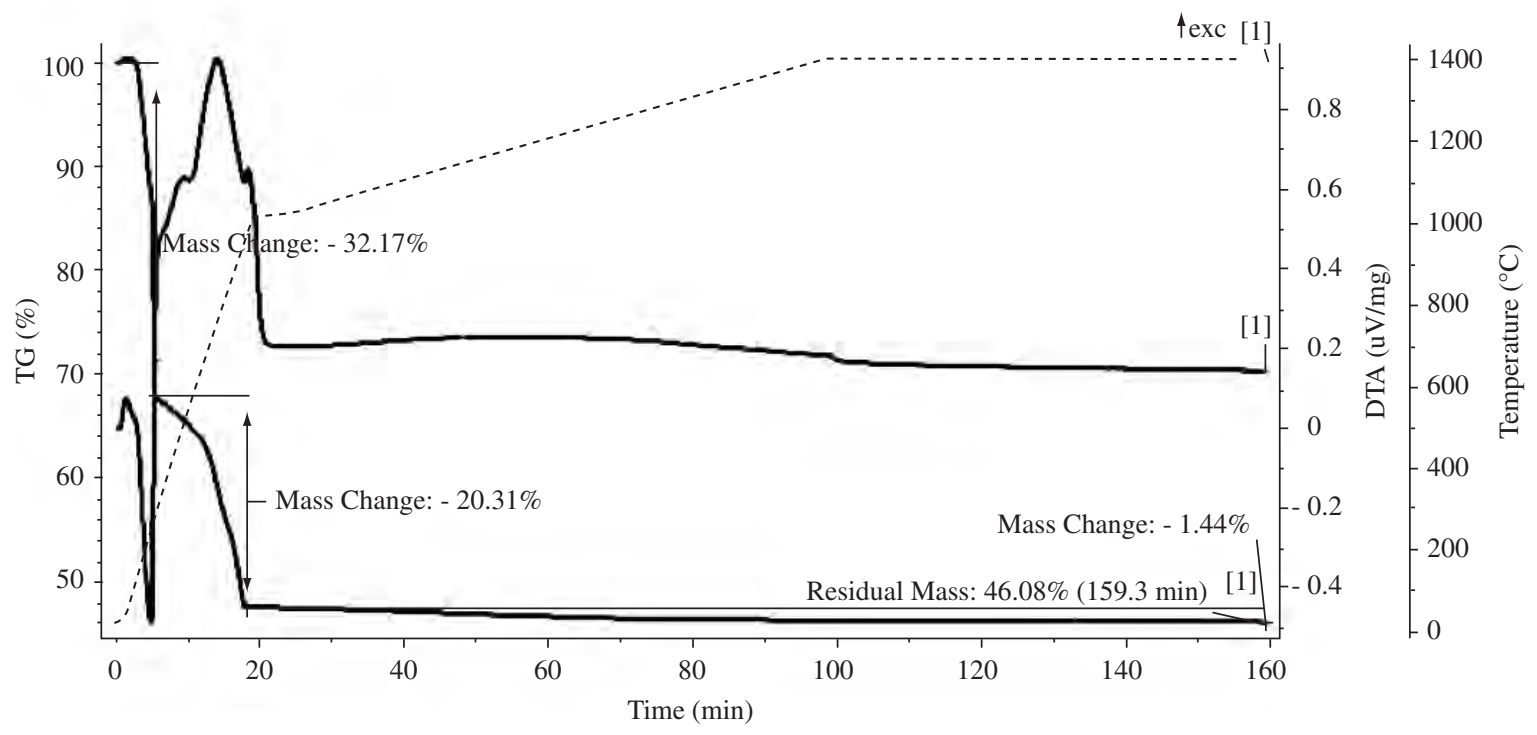

Figure 1. TGA-DTA graph of a sample of coprecipitated triple hydroxide (----- temperature, DTA, TGA). 


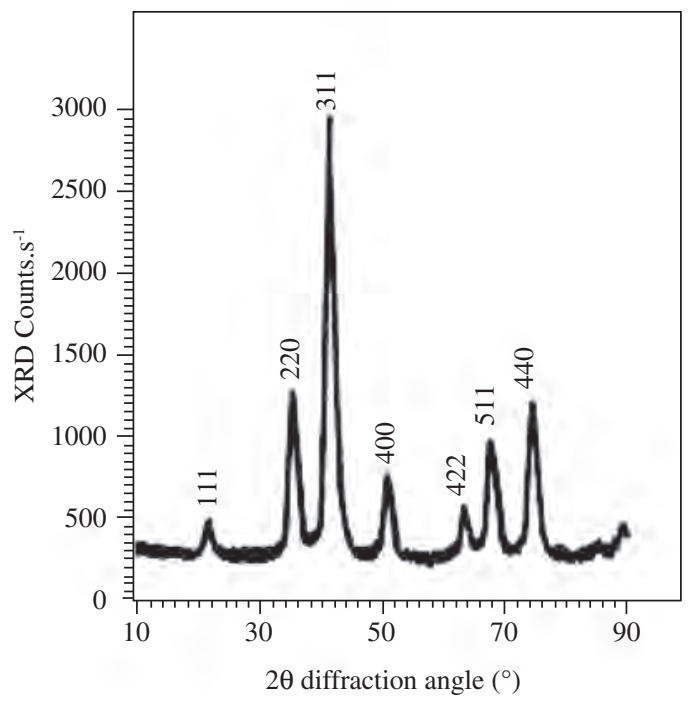

(a)

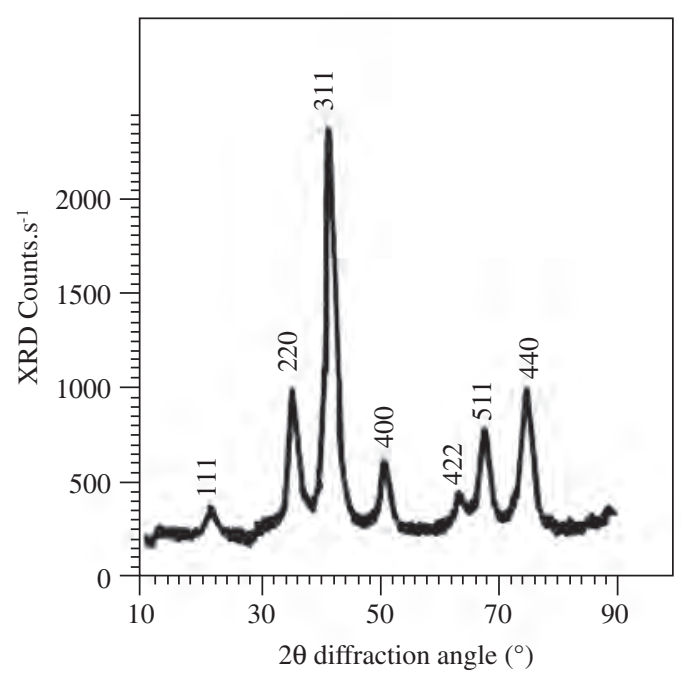

(b)

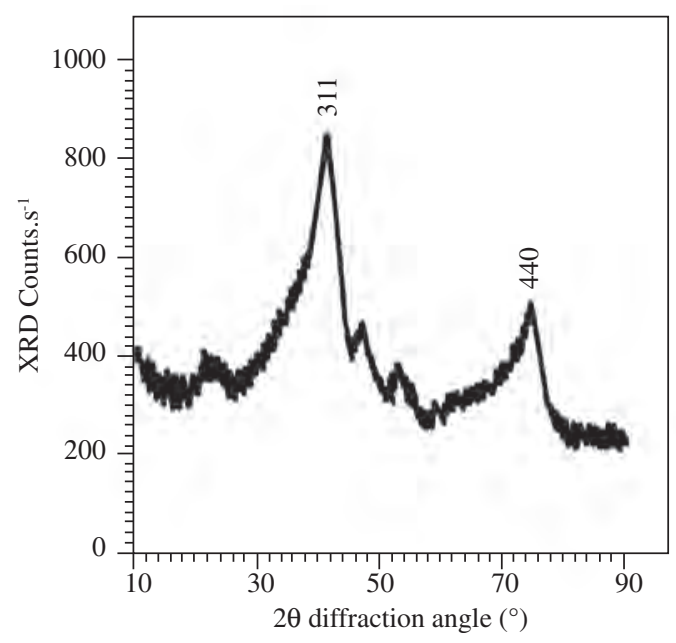

(c)

Figure 2. X ray diffraction patterns of cobalt-zinc ferrites prepared by coprecipitation using as precipitation agent: a) $\mathrm{NaOH}$ and calcined at $400{ }^{\circ} \mathrm{C}$; b) $\mathrm{NH}_{4} \mathrm{OH}$ and calcined at $400{ }^{\circ} \mathrm{C}$; and c) $\mathrm{NaOH}$ and calcined at $200{ }^{\circ} \mathrm{C}$. (calcination time in all cases: 5 hours). grains welded into a continuous mass dispersed in the honeycomb holes. Honeycombing in the material sintered at $1400{ }^{\circ} \mathrm{C}$ (Figure 3f) was so intense that numerous large channels emerged to the sample's surface. This phenomenon is likely related with the decomposition of cobalt-zinc ferrite and loss of zinc by evaporation ${ }^{18-20}$.

The magnetic behavior of $\mathrm{Co}_{0.5} \mathrm{Zn}_{0.5} \mathrm{Fe}_{2} \mathrm{O}_{4}$ was examined. Figure 4 presents the hysteresis curves of the sintered $\mathrm{Co}_{0.5} \mathrm{Zn}_{0.5} \mathrm{Fe}_{2} \mathrm{O}_{4}$ compacts.

Table 2 summarizes the main findings of the material's magnetic behavior.

It can be considered that $\mathrm{B}_{\mathrm{r}}$ (remanescent magnetic induction), $\mathrm{B}_{\max }$ (maximum magnetic induction), HL (magnetic hysteresis loss) and $\mu_{\max }$ (maximum magnetic permeability) increase as the temperature rises from $950{ }^{\circ} \mathrm{C}$ to $1400{ }^{\circ} \mathrm{C}$, while the $\mathrm{H}_{\mathrm{c}}$ (magnetic coercive force) shows the opposite trend, decreasing as the temperature increases in the same range.

The difference in the Hc values is understandable because of the substantial increase in grain size in response to the increase in sintering temperature from 950 to $1350{ }^{\circ} \mathrm{C}$. In other words, above $1100{ }^{\circ} \mathrm{C}$ the mean grain size far exceeded $5 \mu \mathrm{m}$, facilitating the movement of the magnetic domain. However, a comparison of Figures $3 \mathrm{a}$ and $3 \mathrm{~d}$ leaves room for doubt concerning this substantial grain growth. The low coercive force, which confirms that the cobalt-zinc ferrite produced here is a soft ferrite, is congruent with the values reported in the literature ${ }^{1,21}$ for some substituted cobalt-zinc-ferrite powders prepared by coprecipitation.

On the other hand, the values of the other magnetic properties were more difficult to interpret because of the influence of many variables, including the zinc substitution. Tetrahedral sites in the spinel structure are suitable for cationic radii in the range of $0.58 \AA$ to $0.67 \AA$, while octahedral sites can accept cations with radii in the range of $0.70 \AA$ to $0.75 \AA^{22}$. Therefore, in the unit cell structure, $\mathrm{Co}^{2+}(0.72 \AA)$ and $\mathrm{Fe}^{2+}(0.75 \AA)$ may replace $\mathrm{Zn}^{2+}(0.74 \AA)$, while $\mathrm{Co}^{3+}(0.63 \AA)$ can exchange sites with $\mathrm{Fe}^{3+}(0.64 \AA)^{12,13}$. This cation exchange depends on the sintering conditions, since the oxygen partial pressure affects cobalt and iron oxidation states and, hence, influences the magnetic properties of ferrite.

\section{Conclusions}

a) The powder coprecipitation method produced well crystallized cobalt-zinc ferrite powder upon heating the coprecipitated triple hydroxide to $400{ }^{\circ} \mathrm{C}$ for 5 hours, as confirmed by $\mathrm{X}$ ray diffraction;

b) The coprecipitation method provided the densest compact when the green compact was sintered for 5 hours at $1350{ }^{\circ} \mathrm{C}$. Furthermore, the method required relatively low temperatures and short calcination times to produce well crystallized cobaltzinc ferrite powders;

c) Coprecipitated $\mathrm{Co}_{0.5} \mathrm{Zn}_{0.5} \mathrm{Fe}_{2} \mathrm{O}_{4}$ ceramics should be sintered at temperatures up to $1350{ }^{\circ} \mathrm{C}$, as indicated by "honeycombing" degradation of the ceramic sample above this temperature, and by the sharp change in the $\mathrm{X}$ ray diffraction pattern in response to the increase in the sintering temperature from $1350{ }^{\circ} \mathrm{C}$ to $1400{ }^{\circ} \mathrm{C}$; and

d) In spite of the change in the microstructure caused by the sintering process, all the $\mathrm{Hc}$ values were sufficiently low to confirm that the ferrite was a soft ferrite.

\section{Acknowledgments}

The authors thank the Brazilian institutions CAPES, CNPq, FINEP, PADCT, FAPERJ, UFRJ and UFF for their support of this work. 

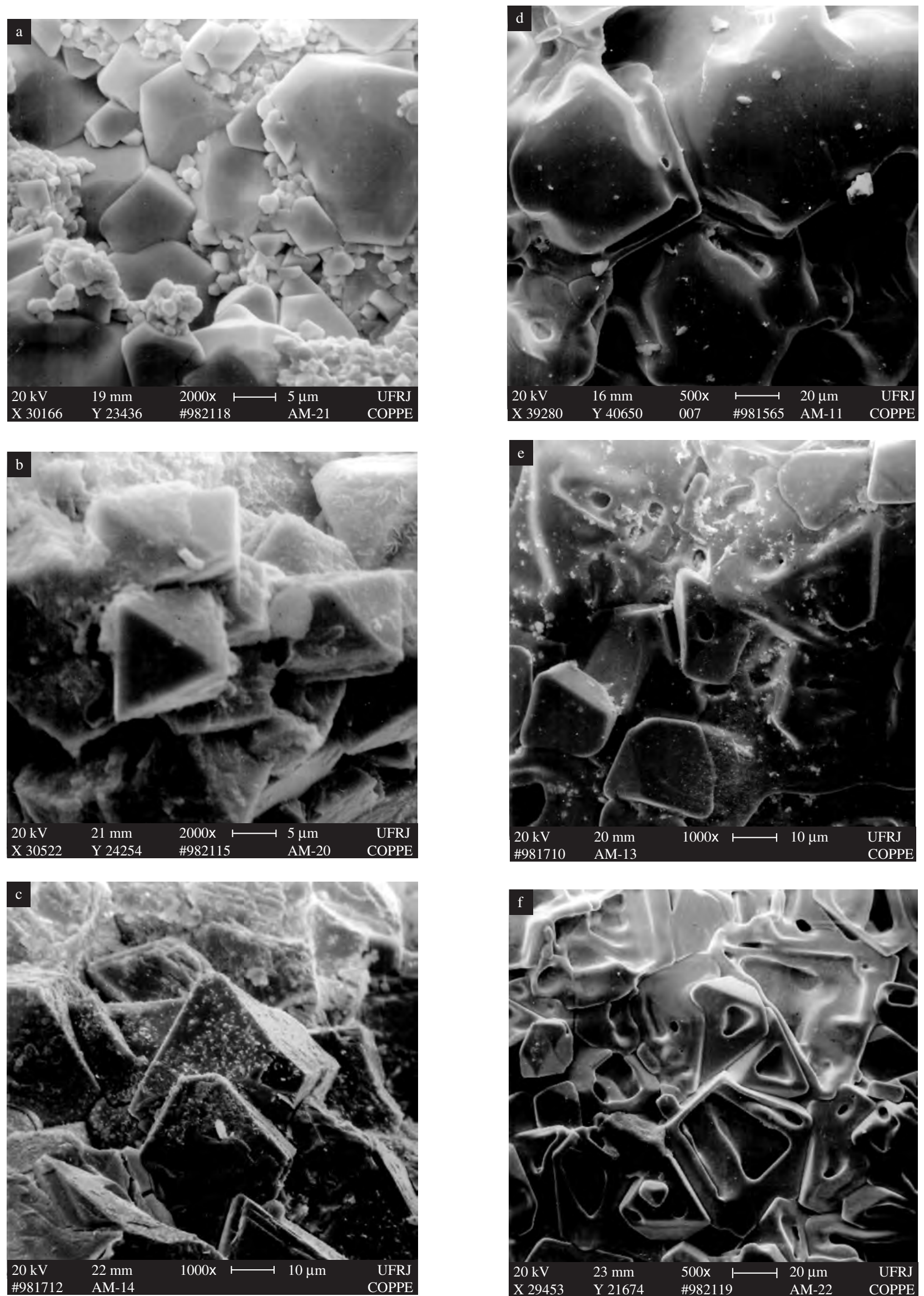

Figure 3. Micrographs of cobalt-zinc ferrite rings sintered for 5 hours at: a) $950{ }^{\circ} \mathrm{C}$; b) $1100{ }^{\circ} \mathrm{C}$; c) $1200{ }^{\circ} \mathrm{C}$; d) $1300{ }^{\circ} \mathrm{C}$; e) $1350{ }^{\circ} \mathrm{C}$; and f) $1400{ }^{\circ} \mathrm{C}$. 

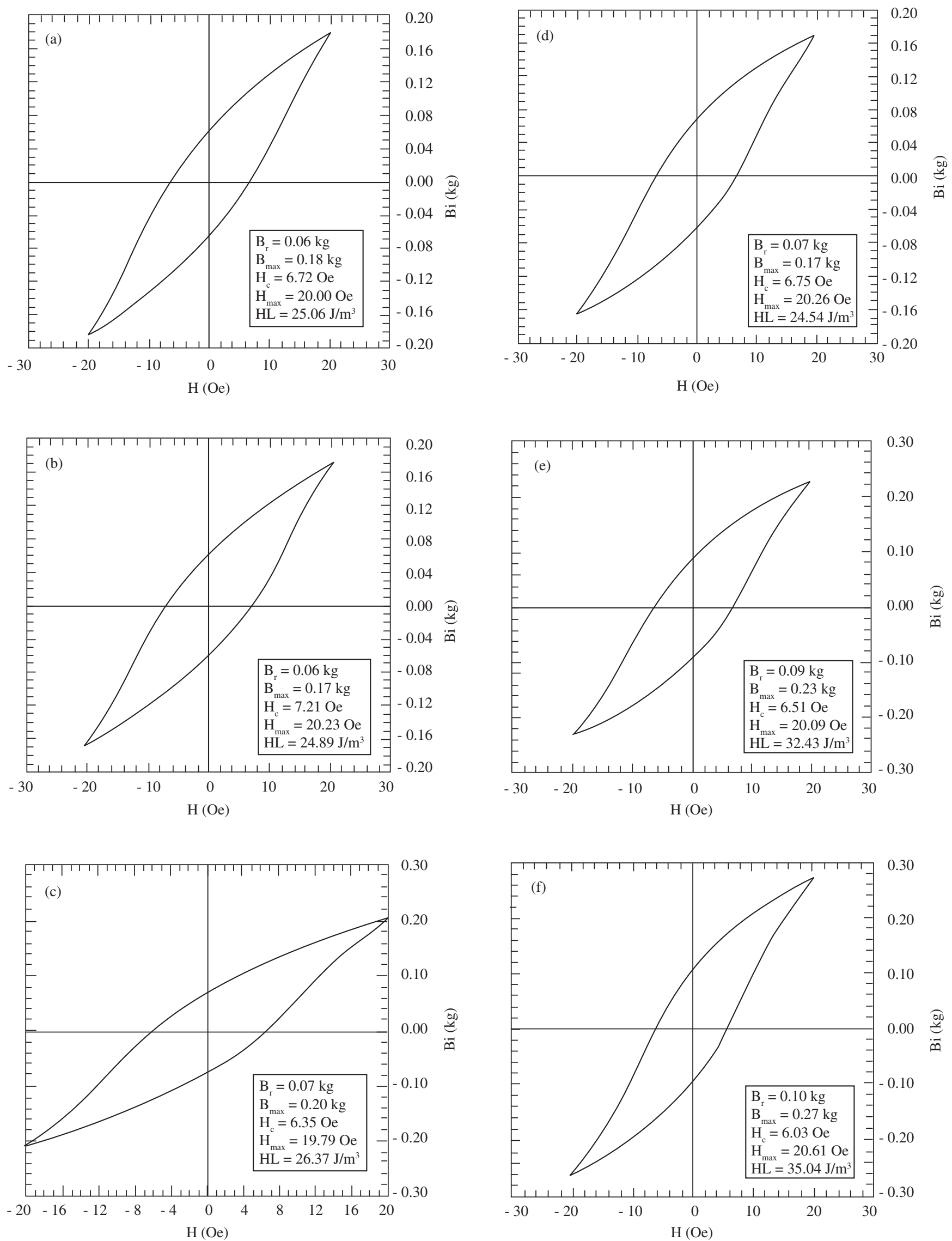

Figure 4. Magnetic hysteresisgraphs of cobalt-zinc ferrite rings sintered for 5 hours at: a) $950{ }^{\circ} \mathrm{C}$; b) $1100{ }^{\circ} \mathrm{C}$; c) $1200{ }^{\circ} \mathrm{C}$; d) $1300{ }^{\circ} \mathrm{C}$; e) $1350{ }^{\circ} \mathrm{C}$; and f) $1400^{\circ} \mathrm{C}$. Frequency $=60 \mathrm{~Hz}$. 
Table 2. Summary of properties of cobalt-zinc ferrites sintered at different temperatures.

\begin{tabular}{ccccccrrr}
\hline $\begin{array}{c}\text { Sintering } \\
\text { Temperature }\left({ }^{\circ} \mathrm{C}\right)\end{array}$ & $\begin{array}{c}\mathrm{Dx} \\
\left(\mathrm{g} / \mathrm{cm}^{3}\right)\end{array}$ & $\begin{array}{c}\text { Co:Zn:Fe } \\
(\mathrm{molar} \text { ratio })\end{array}$ & $\mathrm{B}_{\mathrm{r}}(\mathrm{kg})$ & $\mathrm{H}_{\mathrm{c}}(\mathrm{Oe})$ & $\mathrm{B}_{\max }(\mathrm{kg})$ & $\mathrm{HL}\left(\mathrm{J} . \mathrm{m}^{-3}\right)$ & $\mu_{\max }(\mathrm{G} / \mathrm{Oe})$ \\
\hline 950 & 5.31 & $0.46: 0.45: 1.0$ & 0.06 & 6.6762 & 0.12 & 17.06 & 6.11 \\
1100 & 5.29 & $0.48: 0.46: 1.0$ & 0.06 & 7.2025 & 0.17 & 24.89 & 8.30 \\
1200 & 5.29 & $0.53: 0.51: 1.0$ & 0.07 & 6.3511 & 0.20 & 26.37 & 10.33 \\
1300 & 5.29 & $0.46: 0.48: 1.0$ & 0.07 & 6.7522 & 0.17 & 24.54 & 8.21 \\
1350 & 5.35 & $0.45: 0.44: 1.0$ & 0.09 & 6.5124 & 0.23 & 32.43 & 11.44 \\
1400 & - & $0.47: 0.41: 1.0$ & 0.10 & 6.0322 & 0.27 & 35.04 & 13.00 \\
\hline
\end{tabular}

\section{References}

1. Arulmurugan R, Jeyadevan B, Vaidyanathan G, Sendhilnathan S. Effect of zinc substitution on Co-Zn and Mn-Zn ferrite nanoparticles prepared by co-precipitation. J Magn Magn Mater. 2005; 288:470-7.

2. Virden AE, O'Grady K. Structure and magnetic properties of NiZn ferrite nanoparticles. J Magn Magn Mater. 2005; 290-291: 868-70.

3. Verma S, Joy PA, Khollam YB, Potdar HS, Deshpande SB. Synthesis of nanosized $\mathrm{MgFe}_{2} \mathrm{O}_{4}$ powders by microwave hydrothermal method. Mater Lett. 2004; 58(6):1092-5.

4. Costa ACF, Tortella E, Neto EF, Morelli MR, Kiminami RHGA. Sintering of $\mathrm{Ni}-\mathrm{Zn}$ ferrite nanopowders by the constant heating rate (CHR) method. Mater Res. 2004; 7(4):523-8.

5. Dey S, Ghose J. Synthesis, characterisation and magnetic studies on nanocrystalline $\mathrm{Co}_{0.2} \mathrm{Zn}_{0.8} \mathrm{Fe}_{2} \mathrm{O}_{4}$. Mater Res Bull. 2003; 38(11-12):165360.

6. Pandya PB, Joshi HH, Kulkarni RG. Bulk magnetic properties of CoZn ferrites prepared by the coprecipitation method. J Mater Sci. 1991; 26(20):5509-12.

7. Suzuki K. Preparation of zinc and aluminium substituted Co-ferrite thin films and their faraday rotation. Jpn J Appl Phys. 1988; 27(3):361-5.

8. Ahmed MA. Electrical properties of Co-Zn ferrites. Phys Stat Sol A. 1989; 111: 567-72.

9. Tawfik A. Effect of magnetic order on the conductivity in Co- $\mathrm{Zn}$ ferrites. J Therm Anal. 1989; 35:141-5.

10. Murthy SR, Seshagiri Rao T. Effect of magnetic field and temperature on the elastic behaviour of Co-Zn ferrites. J Less Common Met. 1979; 65:19-26.
11. Murthy SR. Dielectric behaviour of Co-Zn ferrites. J Mater Sci Lett. 1984; 3:1049-51.

12. Abd El-Ati MI, Kafafy MA, Tawfik A. Magnetic properties of zinc doped ferrites. Acta Phys Pol A. 1991; 79(6):889-94.

13. Gaballa GA. Effect of Mn addition on physical properties of $\mathrm{Co}_{0.6} \mathrm{Zn}_{04} \mathrm{Mn}_{\mathrm{x}}$ $\mathrm{Fe}_{2-\mathrm{x}} \mathrm{O}_{4}$ system. Phase Transitions. 1994; 46:66-67.

14. Darwish NZ, Hemeda OM, Abd El-Ati MI. Thermal properties of gamaray irradiated Co-Zn ferrite. Appl Radiat Isot. 45(4):445-8.

15. JCPDS International Centre for Diffraction Data. 2nd ed.,USA; 1979.

16. Abd El-Ati MI. Thermal conductivity of $\mathrm{Zn}$ doped $\mathrm{CoFe}_{2} \mathrm{O}_{4}$ ferrites. Phase Transitions. 1994; 46(4):209-15.

17. Alexéev V. Análise Qualitativa. Porto (Portugal): Editora Lopes da Silva; 1982. p. 302.

18. Drofenik M, Rozman M. Sintering of nanosized MnZn ferrite powders. J Amer Ceram Soc. 1998; 81(7):1757-64.

19. Inaba $\mathrm{H}$, Matsui $\mathrm{T}$. Vaporization and diffusion of manganese-zinc ferrite. J Solid State Chem. 1996; 121(1):143-8.

20. Sainamthip P, Amarakoon VRW. Role of zinc volatilization on the microstructure development of manganese zinc ferrites. J Amer Ceram Soc. 1988; 71(8):644-8.

21. Brownlow JM. Preferential volatilization of cations from ferrites during sintering. J Appl Phys. 1958; 29(3):373-5.

22. Chen CW. Magnetism and Metallurgy of Soft Materials. Netherlands: North-Holland Publishing Co.; 1977.

23. Buchanam RC, Ceramic Materials for Electronics: Processing, Properties and Applications. N. York (USA): Marcel Dekker Inc.; 1986. 